\title{
Ten new records of vascular plants for the flora of Uzbekistan (Asteraceae)
}

\author{
Komiljon Sh. Tojibaev ${ }^{1}$, Natalya Yu. Beshko', Avazbek R. Batashov ${ }^{1}$, \\ Farkhod I. Karimov ${ }^{1}$, Dong-Hyuk Lee ${ }^{2}$, Orzimat T. Turginov ${ }^{1}$, Mansur X. Usmonov ${ }^{1,2 *}$, \\ Ulugbek H. Kodirov ${ }^{1}$ and Dilorom Tajeddinova ${ }^{1}$ \\ ${ }^{1}$ Institute of the Botany and Zoology of Academy of Science of the Republic of Uzbekistan, Tashkent 100125, Uzbekistan \\ ${ }^{2}$ Division of Forest Biodiversity and Herbarium, Korean National Arboretum, Pocheon 11186, Korea \\ (Received 12 July 2017; Revised 4 September 2017; Accepted 22 September 2017)
}

\begin{abstract}
Ten species of vascular plants newly recorded in Uzbekistan are presented. The first record of Anthemis ruthenica from the northern side of the Alay range is confirmed, and the species was found for the second time in a neighborhood of Tashkent as an alien. Carduus arabicus as a native plant in Central Asia is recorded for the first time from Western Pamir-Alay. Chondrilla brevirostris, C. macrocarpa, and C. phaeocephala are from the desert and adyrs zones. Crinitaria tatarica and Crepis mira collected from Western Tien-Shan are presented, Olgaea baldschuanica first recorded on the Babatag range of mountains as a subendemic species and Erigeron andryaloides from the Hissar range are reported here as among the flora of Uzbekistan. The former Centaurea apiculata Ledeb. was accepted as a synonym of C. scabiosa L. subsp. apiculata. All records were collected in different habitats of Uzbekistan. Taxonomic remarks, pictures and distribution maps for these species are provided.
\end{abstract}

Keywords: Uzbekistan, new records, flora, distribution, Asteraceae, native plants

Uzbekistan is a country of Central Asia, located north of Turkmenistan and Afghanistan. With an area of 447,400 square kilometers (land: $425,400 \mathrm{~km}^{2}$, water: $20,000 \mathrm{~km}^{2}$ ), with the mountains covering ca. $15 \%$ of the country (Sennikov et al., 2016). The territory lies between $37^{\circ} 11^{\prime}$ and $45^{\circ} 36^{\prime}$ of northern latitude and $56^{\circ}$ and $73^{\circ} 10^{\prime}$ of eastern longitude, stretches 1,425 kilometers from west to east and 930 kilometers from north to south (Saliev and Kurbanov, 2015). Bordering Turkmenistan to the southwest, Kazakhstan to the north, and Tajikistan and Kyrgyzstan to the south and east, Uzbekistan is not only one of the larger Central Asian states but also the only Central Asian state to border all of the other four. Uzbekistan also shares a short border with Afghanistan to the south (Bushnev and Pritvorov, 2017). As the Caspian Sea is an inland sea with no direct link to the oceans, Uzbekistan is one of only two (Liechtenstein) "doubly landlocked" countries - countries completely surrounded by other landlocked countries (Central Intelligence Agency, 2017).
The elevations vary between 12 (Sariqarnish Kuli, $-39 \mathrm{ft}$ ) and 4,643 m (Khazret Sultan, 15,233 ft) above sea level (http:/ /www.peakbagger.com). Lowlands occupy northern, western and central parts of the country and are largely deserted, except for the depressions of Ferghana, Zeravshan and Surkhon-Sherobod with mild climatic conditions, which are mostly turned into arable lands. The main mountainous systems in Uzbekistan include the Western Tian-Shan and the Pamir-Alay, which are represented by small portions of their territories with most of the larger mountain ranges shared with neighboring countries.

Uzbekistan is a Central Asian country with a rich native flora, assessed at no less than 4,300 native species of vascular plants (Sennikov et al., 2016) and still remaining seriously underexplored. One of the most important and underexplored family in Uzbekistan is Asteraceae. This family presented with the largest number of species in the flora of Uzbekistan with the total number of recorded species which are more than 645 , belonging to 135 genera and constitute a first largest family

\footnotetext{
*Author for correspondence: mansur.usmonov@inbox.ru
} 
in the Uzbek flora. Many of them apparently disappeared and disappearing, rare and reducing species and more than 50 species of the family included in the Red Book of Uzbekistan. The most important source of floristic information is Central Herbarium of Institute of Botany and Zoology of Academy Science of Uzbekistan (TASH), the largest collection of Central Asian plants in the world. There are over 1.5 million herbarium specimens collected since 1840 from all regions of the Central Asia (Tojibaev et al., 2014).

Ten previously unrecorded species Anthemis ruthenica Bieb. from the N Alay range and neighborhood of Tashkent region, Carduus arabicus Jacq. from Western Pamir-Alay (Hissar, Zeravshan and Kurama ranges) as a native plant, Chondrilla brevirostris Fisch. et Mey., Chondrilla macrocarpa Leonova, Chondrilla phaeocephala Rupr. from the Ustyurt, Kyzyl-kum desert and Adyrs zones, Crinitaria tatarica (Less.) Czerep. and Crepis mira (Pavlov) Sennikov rom Western Tien-Shan, Olgaea baldschuanica (C. Winkl.) Iljin from Babatag Mts., and Erigeron andryaloides (DC.) Benth. ex C. B. Clarke from Hissar range were found during 2011-2017 field expeditions and examination of herbarium specimens of TASH.

This paper provides information about ten newly recorded species for the flora of Uzbekistan. The aim of this paper is to report new noteworthy records for ten vascular plant species belongs to eight genera in the family Asteraceae from Uzbekistan. Taxonomic remarks and distribution map for these species are provided.

\section{Materials and Methods}

New records of vascular plants from Uzbekistan were screened and checked against published information and literatures (Kamelin and Kovalevskaya, 1993, Lazkov and Sultanova, 2014, Christenhusz and Byng, 2016, Yang at al., 2016). This revision is based on the collections of TASH, authors' collections and field observations. The collection locations of specimens were mapped using a GPS navigator with WGS84 Geographic coordinate system as a reference datum. We studied all herbarium specimens of Asteraceae collected from Uzbekistan (total more than 22,000 specimens). We also investigated the Herbarium of the Komarov Botanical Institute, St. Petersburg (LE) (Tojibaev visited in 2016). Plant material collected in different part of Uzbekistan and complied in the herbarium of TASH was studied.

\section{Results and Discussion}

We found ten new records belong to eight genera for the flora of Uzbekistan. Of these, three species were found during field expeditions (below given pictures), seven of them were found during examination of herbarium specimens of TASH.

\section{New records}

Anthemis ruthenica Bieberstein 1808.-TYPE: Described on the materials from Crimea and Ukraine.

Anthemis ruthenica is a species in the genus Anthemis which contains approximately 222 to 315 species. According to Kamelin and Kovalevskaya (1993), A. ruthenica for the Middle Asia in the Flora USSR was not specified. Even, Khalkuziev (1971) did not report about this species for the flora Shakhimardan river basin. However, some specimens were found in LE and determined by A.A Fedorov as an $A$.

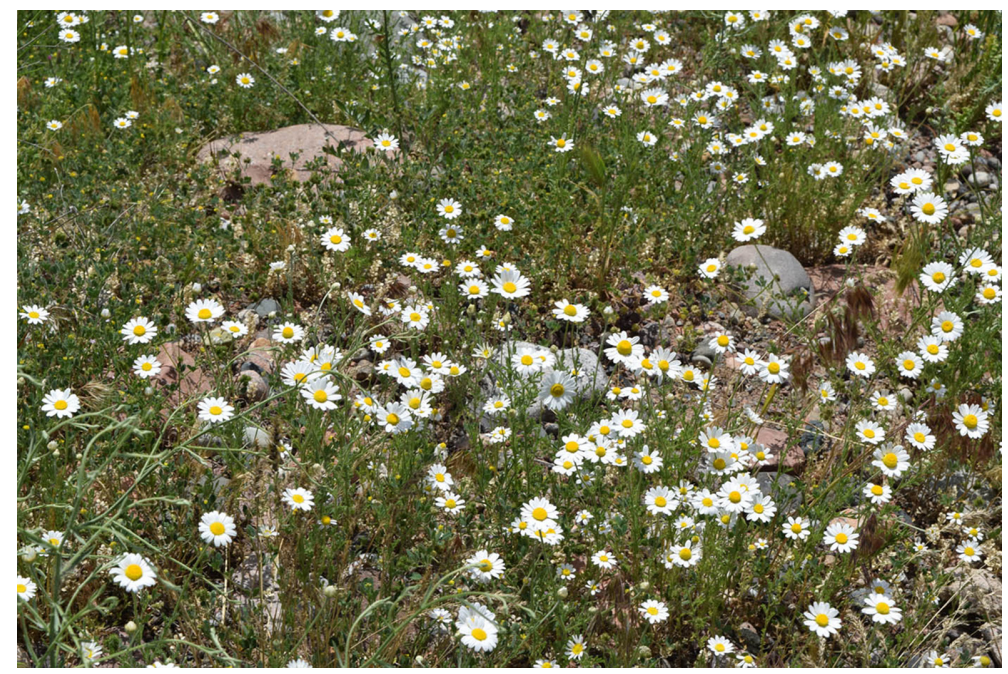

Fig. 1. Local distribution of Anthemis ruthenica in roadside curb between cities Chirchik and Gazalkent, 4 May 2015. Photo: T. Tillaev. 
ruthenica. Based on these collections the species included in the ordinary volume 10th Conspectus Florae Asiae Mediae released in 1993. Orazova (1966) presented 51 species in the former Soviet Union (USSR) territory. Eleven of them recorded in Central Asia (Kamelin and Kovalevskaya, 1993). Earlier it was known from W Kopetdagh Range, Kara-kala Mts. (Turkmenistan), NE parts of Kyrgyz Alatau in Kyrgyzstan. During revision of herbarium materials from the genus Anthemis, we found several specimens of A. ruthenica collected from different countries of Central Asia and also in Uzbekistan. The species was first reported from Uzbekistan on the basis of a single recent collection from Sadkak village on the Northern side of Alay range (Khalkuziev s.n., 1965). The species is also known from the northern part of the Tashkent region in roadside curb between cities Chirchik and Gazalkent (Fig. 1). It was observed by T. Tillaev (without voucher specimens) and species was determined by G. Lazkov.

Specimens examined: Uzbekistan. Pamir-Alay. Alay range, river basin Shakhimardan, neighborhood of Fergana city, Sadkak. Stony places, 7 May 1965, Khalkuziyev s.n. (TASH). Kyrgyzstan. Kyrgyz SSR. Frunze region, Kyrgyz Alatau, the gorge River Aspara, on the river bank, 22 Jul 1948, Skorik s.n. (TASH). Turkmenistan. Western Kopet-Dag. The surrounding mountains of Kara-Kala, Turkmen fields, 23 Jun 1934, Popov s.n. (TASH).

Distribution: Native to Central Europe, Eastern Central Europe, Eastern Europe, the Caucasus and the Balkan Peninsula (French at al., 1999). Also found in Kazakhstan, and Kyrgyzstan as an alien, naturalized and invasive (Sennikov and Lazkov, 2014). In Uzbekistan was found as a weed along roads, on the banks of irrigation ditches and stony places of Northern Alay range.

Carduus arabicus Jacquin 1784.-TYPE: Described from Arabia, Paris (P), but unclear.

Rasulova and Sharipova (1991) reported this species for Tajikistan, including Zeravshan, Karatau, Kaykitau, Sipoktau and Aruktau mountains valley. In TASH, there are detected several herbarium specimens collected from Pamir-Alay and Western Tien Shan Mountains system from territory of Uzbekistan (Figs. 2, 3). This species has not been previously recorded from Uzbekistan and distribution range in Central Asia area is in Tajikistan and Kazakhstan.

All cited specimens from Uzbekistan, Kazakhstan and Tajikistan belong to $C$. arabicus.

Specimens examined: Uzbekistan. Tashkent City, 19 Mar 2016 Gaziev s.n.; Fergana Valley, Andijan region, foothill near the village of Chilon, 12 Jun 2015 Tillaev (without

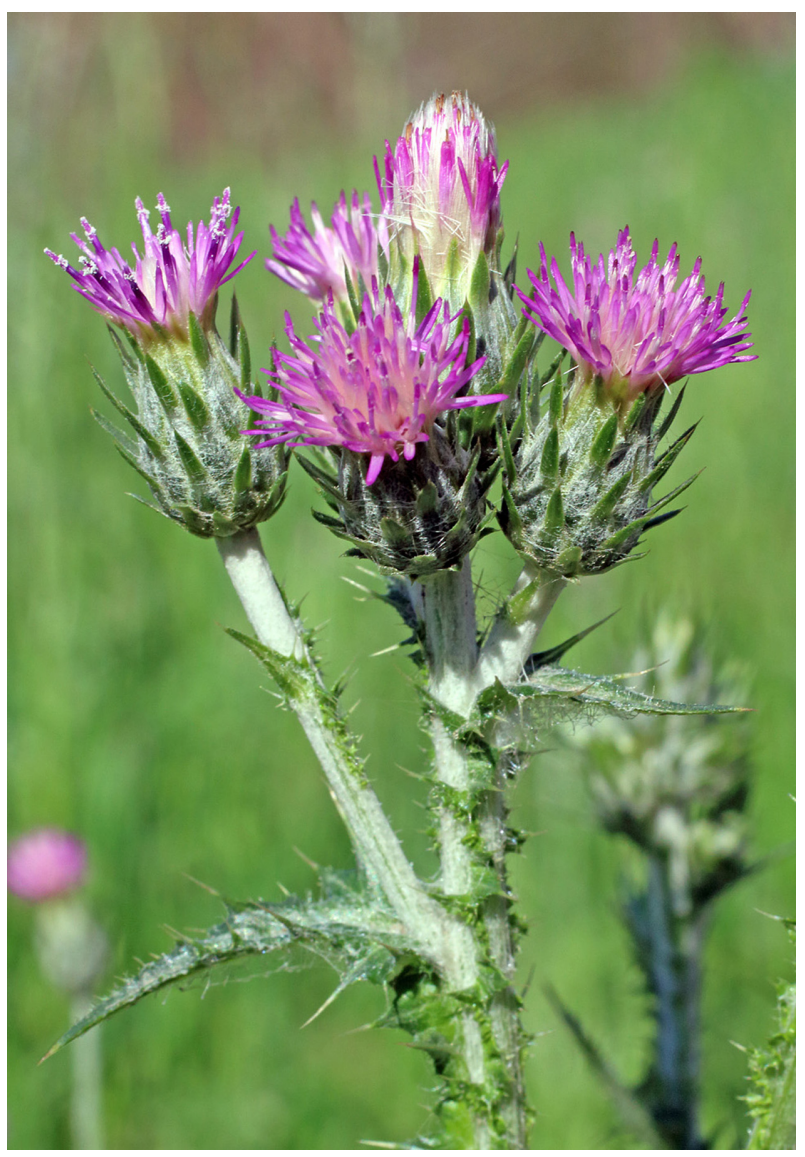

Fig. 2. Upper shoot with inflorescences of Carduus arabicus in the city Tashkent, 19 Mar 2016. Photo: A.Gaziev.

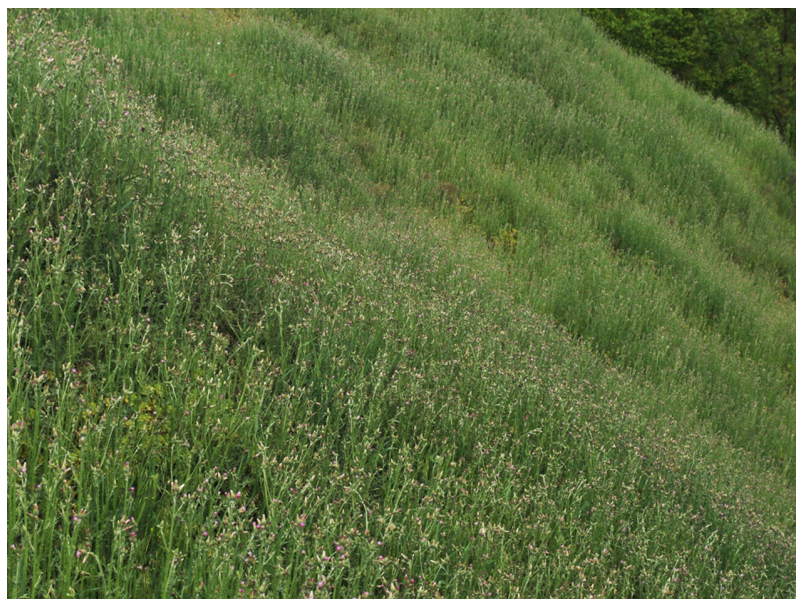

Fig. 3. Flowering plants on the slope, Tashkent, Aktepa Yunusabad, 10 Apr 2016. Photo: T.Tillaev.

voucher); Zeravshan range, Takhta-Karacha pass, on the road to Kitab, 8 May 1959, Korotkova 6568; River valley KashkaDarya, in left river bank Aksu, for Jar-Kurgan, 8 Jun 1937, 
Kudryashev 350; Kashka-Darya river basin, neighborhood Chirakchi, a park, 9 May 1938, Kudryashev 116; Urya-Darya river valley, in say valley, 17 May 1959, NIyazov 456; Tashkent city, in the road of Nizamy Pedagogical Institute, 16 May 1962, Sultanov s.n.; left river bank Surkhan-Darya, at the $1.5 \mathrm{~km}$ to SE from vill. Uzunkishlak 30 May 1941, Gromakov 32; River basin Angren, Бассейн р. Ангрен, north of the village Uboy-itti, 18 May 1939, Pinkhasov; Tashkent, Akademgorodok, 4 May 1971. Lorotkova s.n.; River valley Angren, No.68 farming Urazaevka 9 May 1933, Poslavskaya 177; Pamir-Alay, Nuratau Mts., 20 Apr 1963, Khaydarov 1017; River valley Tupalang, neighborhood vill. DegiKalandar, farm Yangi-Tashkilot, 7 May 1941, Lopott 77 (all TASH).

Some specimens were collected from territory of Kazakhstan and Tajikistan.

Kazakhstan. Mountains Korjantau, 7 Jun 1937, Guschin \& Dzhanaeva (TASH); Tajikistan. s/f Vakhsh, 2-farm, 2 Jun 1934, Potopolsky s.n. (TASH).

However, C. arabicus was not included in the vol. 10 of Conspectus Florae Asiae Mediae (1993).

Distribution: Indigenous, originating from the Maltese islands. Also known from Antarctica, Greece, Sweden, Turkmenistan, Kazakhstan and Tajikistan. In Uzbekistan this species described as very common in roadsides, other waste places, uncultivated ground, fields, fields, foothills and the middle belt of mountains.

Centaurea scabiosa L. subsp. apiculata (Ledeb.) Mikheev 2000.-TYPE: Crimea ("inter Sympheropolin et KarassuBasar") in LE.

Species with distribution area of Caucasus, Western Siberia, the middle part of Western Europe, Mediterranean and Balkans. C. scabiosa L. subsp. apiculata is a member of sect. Lopholoma (Cass.) DC. with 9 species. (Tzvelev, 1963). According to Makhmedov (1993) this species widespread of Priaral deserts of Kazakhstan. However, during field expedition in 2011-2012 to Ustyurt we found of C. scabiosa L. subsp. apiculata from the Uzbek part of the Eastern chink of Ustyurt plateau (Fig. 4).

Specimens examined: Uzbekistan. Eastern chink of Ustyurt, gypsum soils, 31 May 2011, Shomurodov s.n.; Northern part of the Eastern chink, the gypsum, 29 May 2012, Tazhetdinova s.n.(TASH).

Distribution: Native to Southeastern Europe, Caucasus, W Siberia, found in the gypsum zone from the Uzbek part of Ustyurt plateau.

Chondrilla brevirostris Fischer et Meyer 1837.-TYPE:
Described from the Altai (LE), but specimen was not mentioned in the description.

According to Togayev (1991), this species is widespread in Kazakhstan and Kyrgyzstan on Western and Central Tien Shan Mountain. Chondrilla sect. Chondrilla Endl. is represented in Central Asia by 22 species. They are the local endemics of Western Tien-Shan Mountains. 5 of them were recorded for Uzbekistan (Kovalevskaya, 1962). According to Lazkov and Sultanova (2014) C. brevirostris is subendemic and widespread in Kyrgyzstan on Kirghiz, Kungey Ala-To, Terskey Ala-Too, Ferghana, Kokshaal-Too ridges, Talas and Chatkal valleys (Lazkov and Sultanova, 2014). There are several specimens of species collected from Kazakhstan and Kyrgyzstan, only one specimen from the Uzbek part of the river basin Syrdarya (Fig. 5).

Specimens examined: Uzbekistan. Syr-Darya valley. Sand stripes near the village Sart-Yuz, 20 Sep 1958, Butkov 23 (TASH).

Distribution: Native to Altai, W Siberia and for Kazakhstan, Kyrgyzstan, Russia (W Asian and E and S European parts). The species is also known from the territory of Uzbekistan.

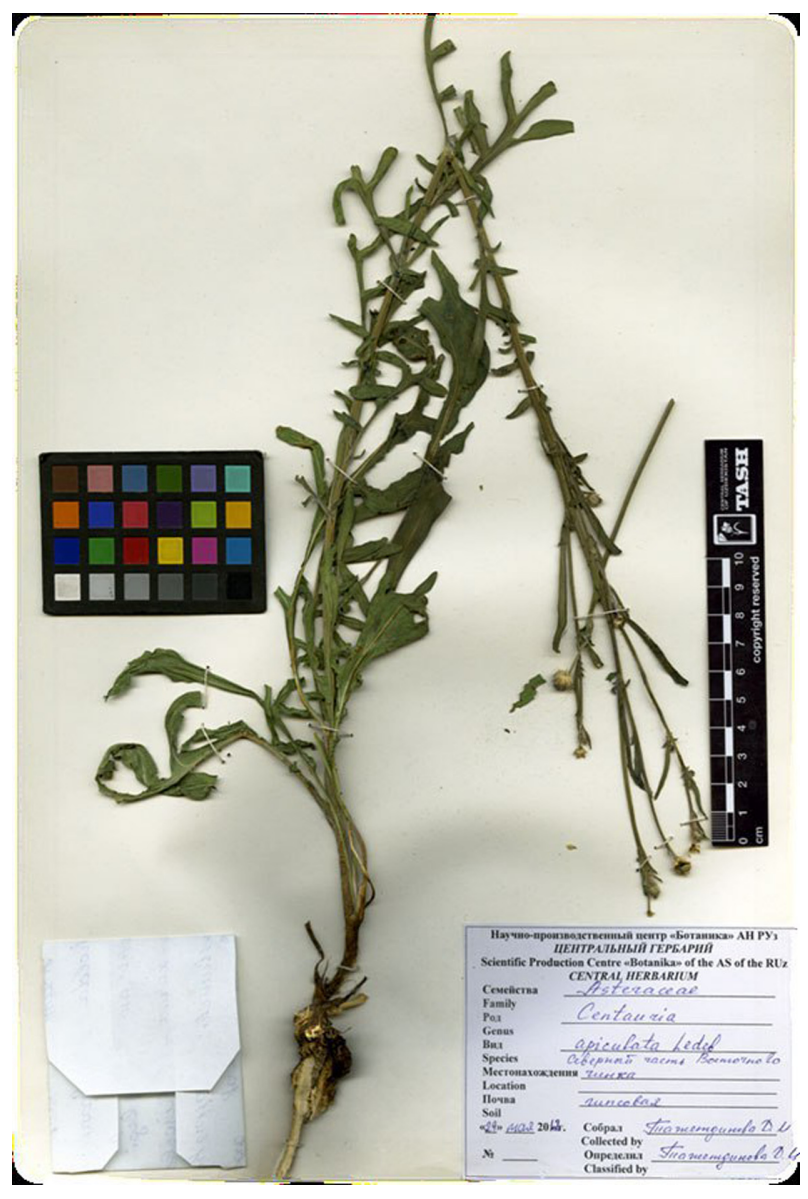

Fig. 4. Presentative specimen of C. scabiosa L. subsp. apiculate. 


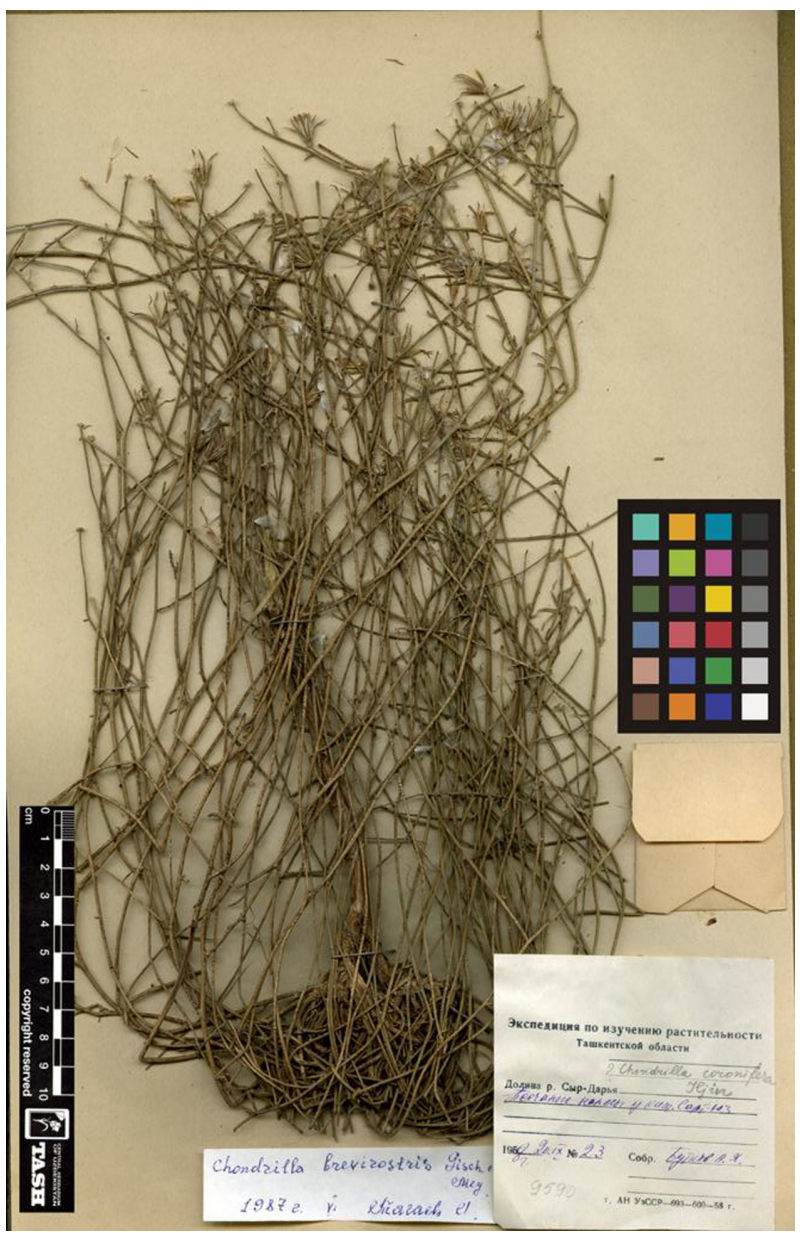

Fig. 5. Representative specimen of Chondrilla brevirostris.

Chondrilla macrocarpa Leonova 1964.-TYPE: Uzbekistan. Karakalpak Kyzylkum, Kuldar village, hilly, slightly broken sand, 20 Sep 1932, Muravlyansky s.n. (LE).

According to Leonova (1964) C. macrocarpa belonging to subg. Brachyrhynchus (Iljin) Leonova with 6 published species in Central Asia (Leonova, 1964). It is a second species from this subgenus to the flora of Uzbekistan. During revision of herbarium material of TASH, we found four specimens of Chondrilla macrocarpa, collected in a Central and NE part of the Kyzyl-Kum and from Ustyurt desert in the border zone of Uzbekistan and Kazakhstan (Fig. 6). Individuals of the species can probably be found in both of these countries.

Specimens examined: Uzbekistan. Kyzyl-kum. Buzau-Bai massif, at $26 \mathrm{~km}$ on the E-S-E the count of Er-Mukan (Ayutugen), 13 Sep 1954, Adylov 279 (TASH); Karakalpakistan. Ust-Yurt, in $1 \mathrm{~km}$ to the WNW from the Takhtu-Tusha well, 20 Jun 1949, Momotov 881 (TASH).

Distribution: Native to Uzbekistan, growing in the desert

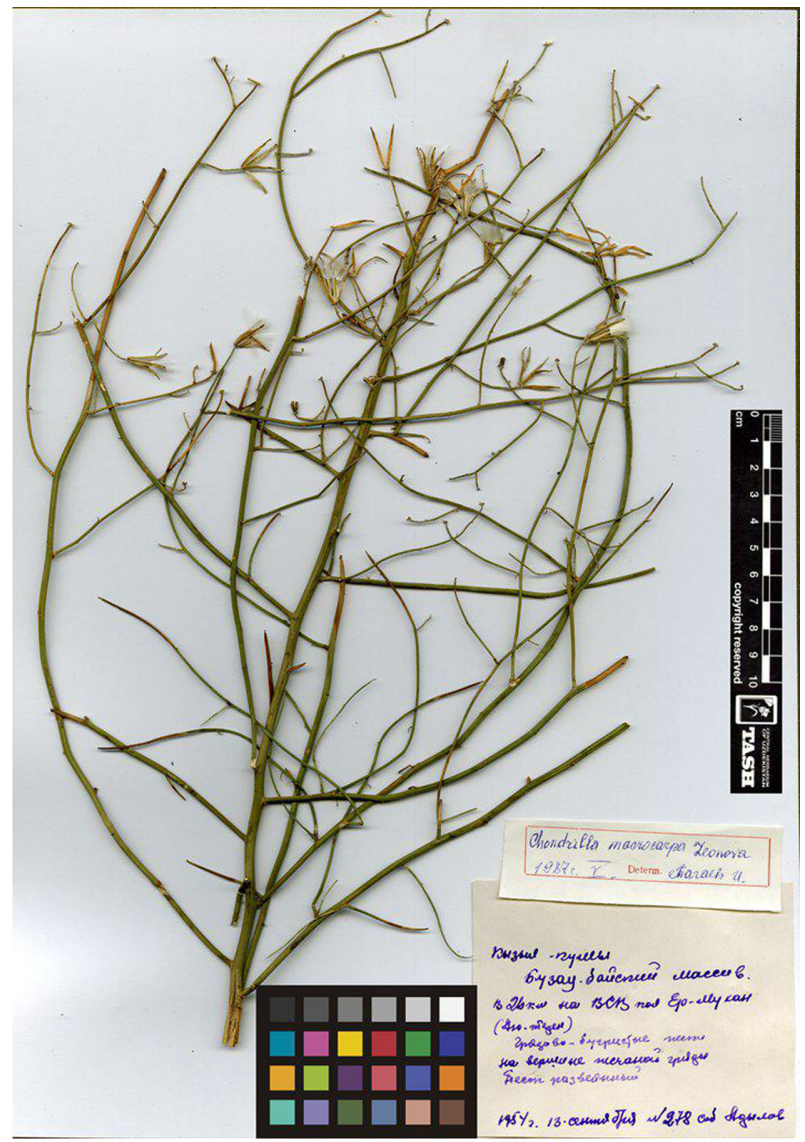

Fig. 6. Representative specimen of Chondrilla macrocarpa.

zone (Kyzyl-rum, Ustyurt), also in Turkmenistan (AralCaspian) and Kazakhstan (Pribalkhash).

Chondrilla phaeocephala Ruprecht 1869.-TYPE: Described from Tien-Shan (LE).

Chondrilla phaeocephala is the third species of the sect. Arthrorhynchus Frisch. et Mey. for the Uzbek flora. This species is characteristic element of alpine grasslands in the high alpine belt and grows on stony slopes at an elevation of 4,000 $\mathrm{m}$ in Afghanistan and Pakistan regions bordering Tadzhikistan (Leonova, 1964). During the examination of TASH we found several specimens of this species collected since 1915-1976. Only three specimens were collected from Uzbek part of Alay range (Fig. 7). But one of them sine auctoris (sine auc.).

Specimens examined: Uzbekistan. Alay range, $\mathrm{N}$ slopes of the river basin Isfayramsay, neighborhood of vill. Muyan, adyr, 31 Aug 1958, sine ouc; ; Alay range, Halmion region, Batken detachment. 1940, Lopott \& Pinkhasov 321, 425 (TASH).

Distribution: Tajikistan, this species distributed in the Northern Alay in the territory of Uzbekistan. 


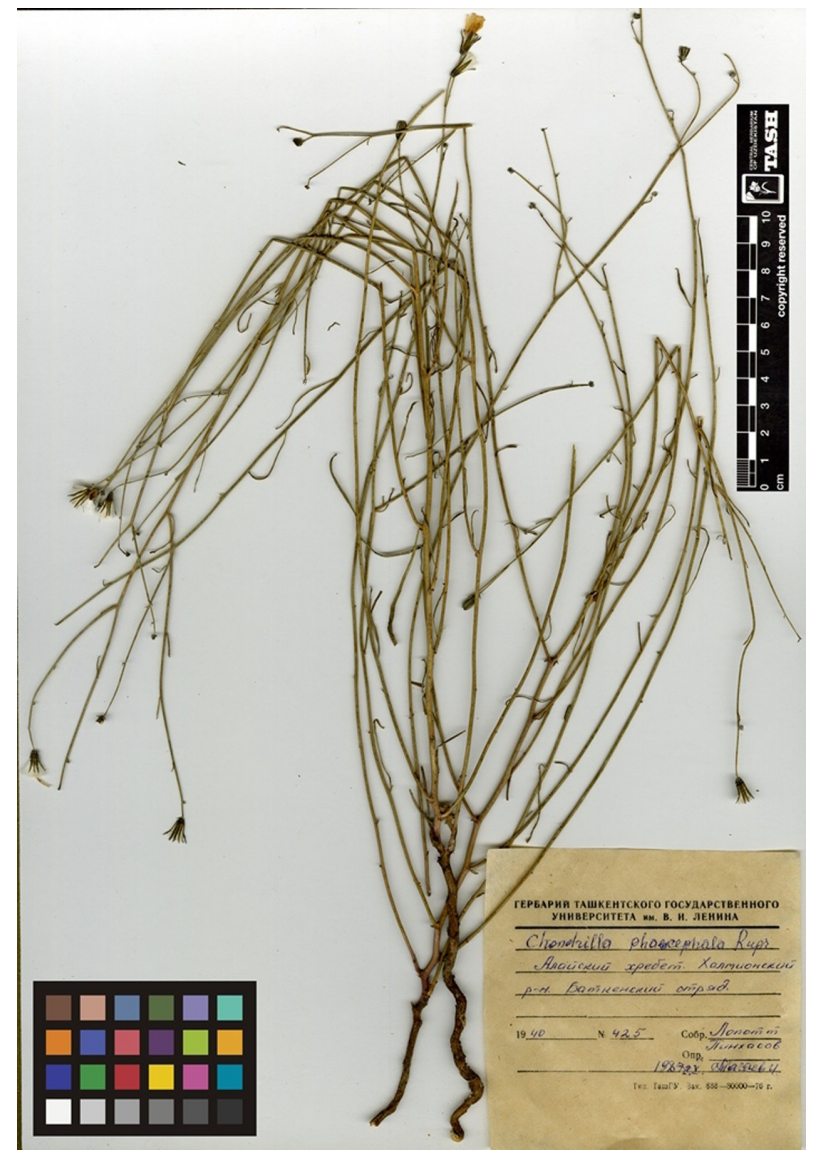

Fig. 7. Representative specimen of Chondrilla phaeocephala.

Crinitaria tatarica (Less.) Czerepanov 1981.-TYPE: Southern Urals (vicinity of the towns of Orsk and Sol-Iletsk) in LE.

Previously $C$. tatarica was known from Kazakhstan as a synonym of Linosyris tatarica (Less.) C. A. Mey. (Tzvelov, 1959). Currently this species was renamed as Crinitaria tatarica. Only two species presented for Central Asia by Tulyaganova (1993) and they are endemics of Kazakhstan. It was not listed in the flora of Uzbekistan to date (Tojibaev et al., 2017), although one location from the territory of Uzbekistan in W Tien-Shan Mts. was mentioned by Petrov (1960). Our specimen makes the first record of this species from Uzbekistan (Fig. 8).

Specimens examined. Uzbekistan. Pskem range, south of the upper hole Besh-Torsay, an altitude of 3,000 m. 29 Aug 1960, Petrov (TASH).

Distribution: native to Russia (W Siberia: Altai), Kazakhstan, also was found in China, Europe. and Uzbekistan.

Crepis mira (Pavlov) Sennikov 2000.-TYPE: Kazakhstan.

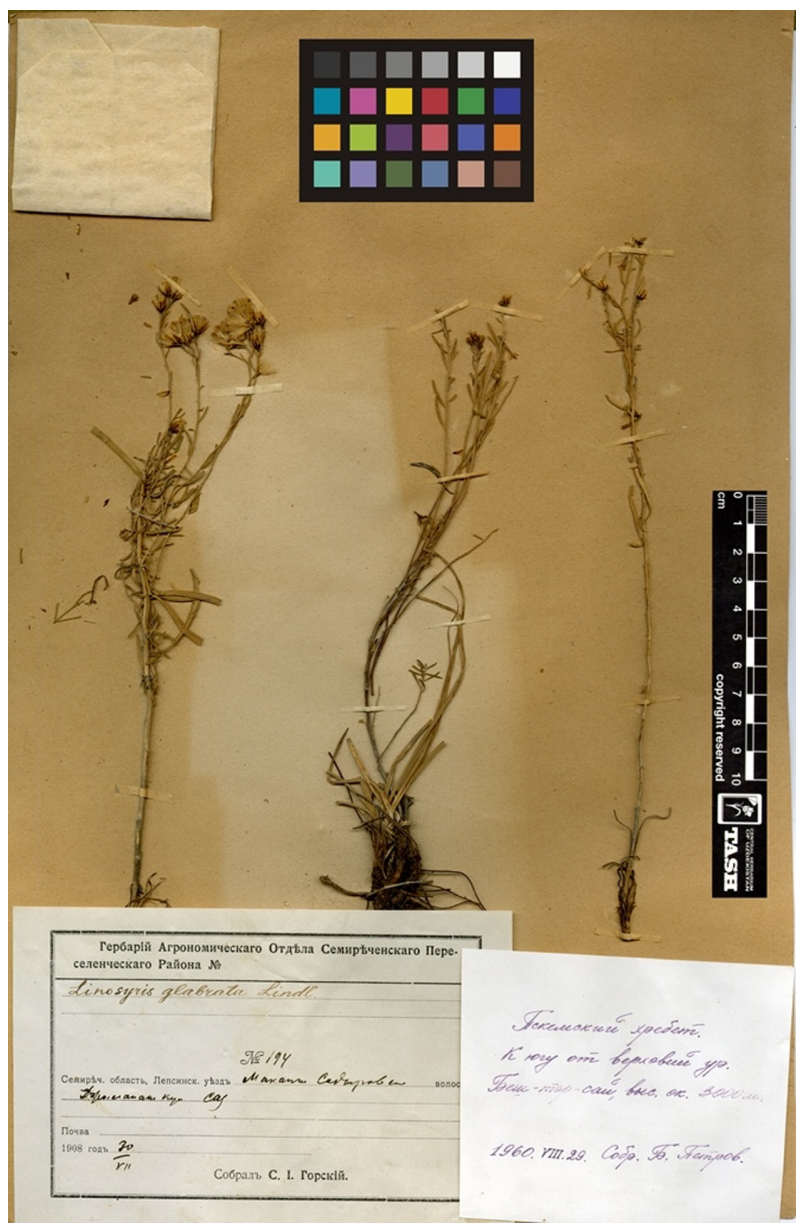

Fig. 8. Representative specimen of Crinitaria tatarica.

River Dzhebogly-Su (Bagdasarova, Gubanov, 1975: 353) MW, isotype in LE.; Lactuca mira Pavlov, Byull. Moskovsk. Obshch. Isp. Prir., Otd. Biol. 1933, n.s. XLII. 128, 147.; Prenanthes mira (Pavlov) Kamelin, Opred. Rast. Sred. Azii 10: 131, 1993.

Crepis mira the sixth additional species of the genus Crepis L. in the flora of Central Asia. This species, widely distributed in the Southeastern Kazakhstan and Northwestern Kyrgyzstan (Aydarova, 1965; Karmyscheva, 1966). The specimens of C. mira kept at TASH are listed and mapped here to provide the background for the species distribution in the country.

During examination of TASH collection were found four specimens collected by Kultiasov (Kultiasov 789, 790, $791,792,1928)$ at the same place from Pskem River valley (Fig. 9).

Specimens examined: Uzbekistan. W Tien Shan. On the way from the Tepar-say pass in the river valley Pskem to the river Ugam, 23 Aug 1928, Kultiasov 789, 790, 791, 792 (TASH). 


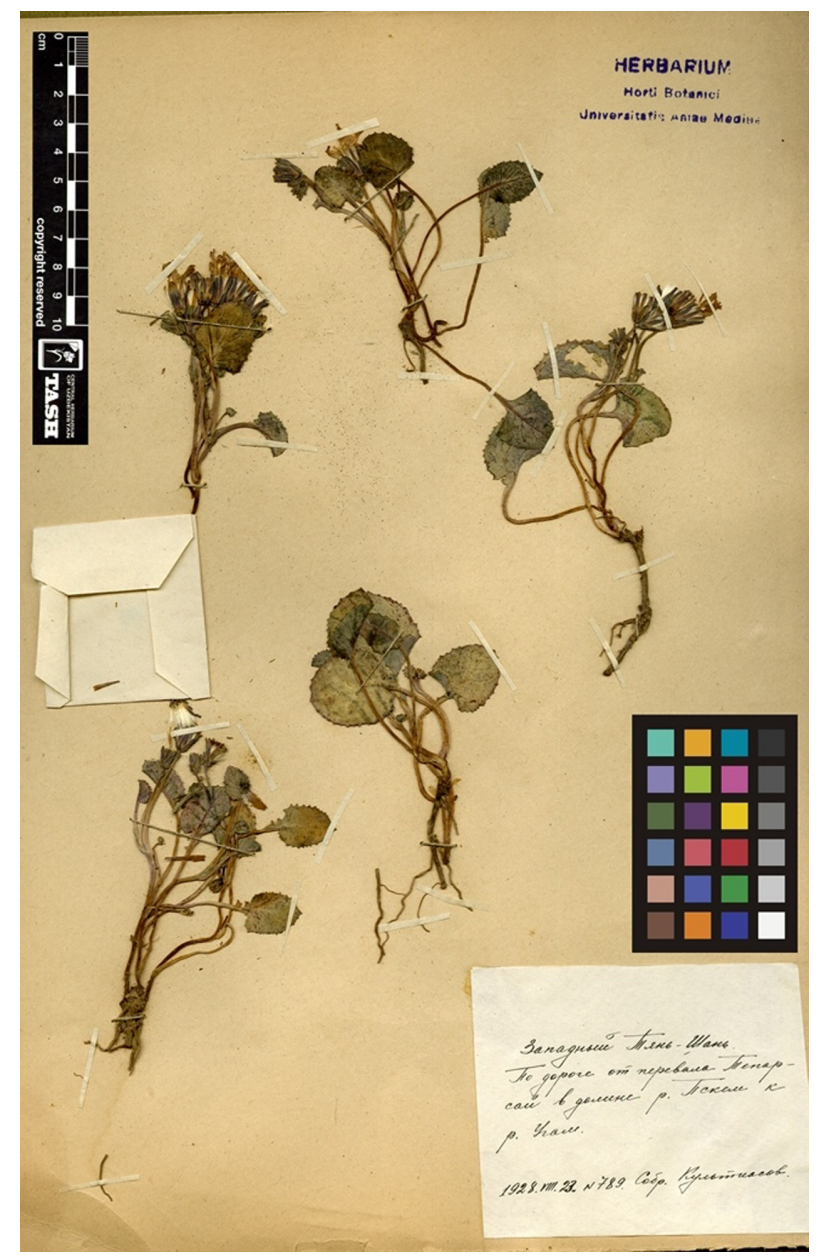

Fig. 9. Representative specimen of Crepis mira.

Distribution: Native to Kazakhstan. The species also found in Kyrgyzstan and Uzbekistan.

Olgaea baldschuanica (C.Wink1.) Iljin 1922.-TYPE: Tajikistan. Baldschuan. Inter Chodscha-Kala et Talbar, 7,0008,000 ft., Jul 1882, Regel, A. s.n. (syntype W, type LE).

New additional subendemic species from Uzbek part of the mountains Babatag. It is second species from the genus Olgaea for the territory and the flora of Uzbekistan. According to Scharipova (1991) the distribution area of this species located within Tajikistan (Alay, Hissar Petr I, Babatag ranges and Mts. of South Tajikistan) and considered as endemics species. We registered it from western part of Babatag Mountains (Fig. 10). It was previously known only from Tajikiistan.

Specimens examined: Uzbekistan. Babatag range, SharShar, 7 Aug 1936, Vedeneeva (TASH); South-western PamirAlai. Mountains of Baba-tag. Exposures of gypsum-bearing clays in the village of Nabat, 28 Jul 1936, Lepeshkin \&

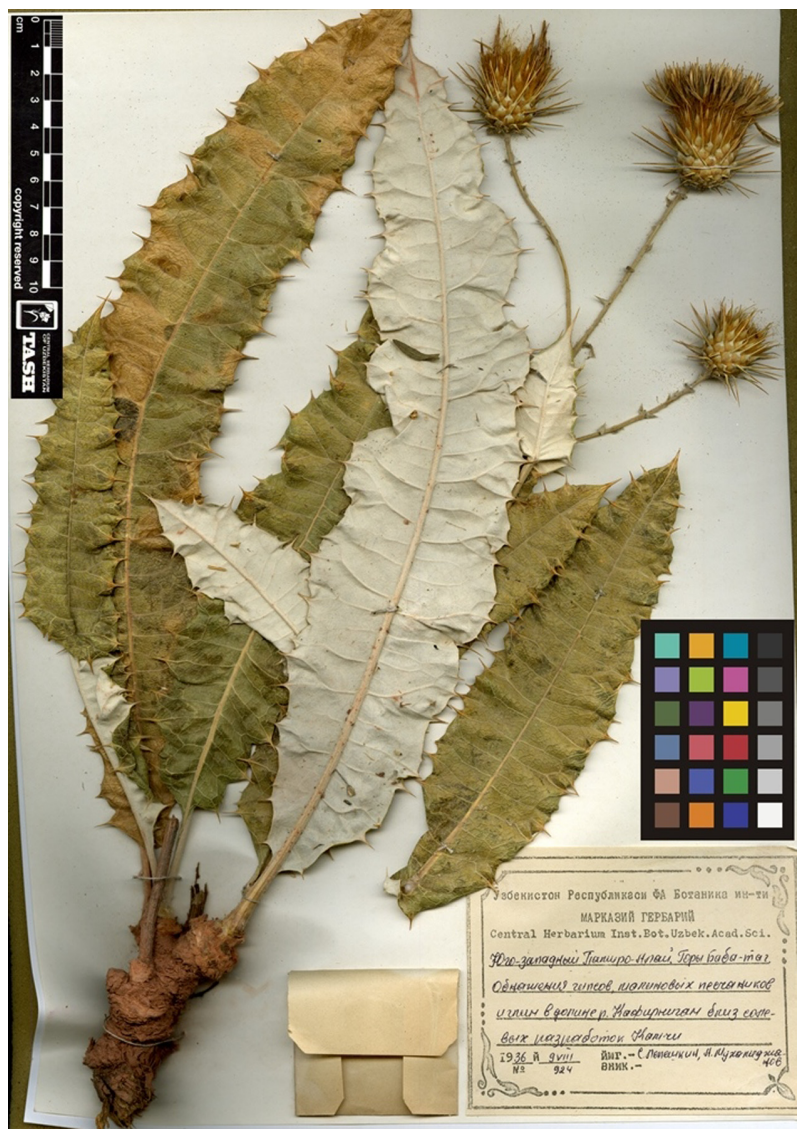

Fig. 10. Representative specimen of Olgaea baldschuanica.

Mukhamedzhanov 730 (TASH); South-western Pamir-Alay, Mts. Babatag, between vv. Psta-Mazar and Duob, 4 Jul 1936, Lepeshkin, Mukhamedzhano 424 (TASH).

Another examined specimens from Tajikistan: Tajikistan. South-western Pamir-Alay, Mts. Babatag, river valley Kafirnikan, 9 Aug 1936, Lepeshkin, Mukhamedzhanov 924, 929 (TASH); Tajik SSR. Peter I range, on the right side of the river Obihinguow, the gorge of the river Daranob, among the exochorum on the red stony-gravelly slopes, 7 Aug 1963, Korotkova, Tayjanov 10038 (TASH).

Distribution: Uzbekistan (within Babatag Mts. and near to the borders of Tajikistan).

Erigeron andryaloides (DC.) Benth. ex C. B. Clarke 1876. -TYPE: India. Cachemire, 1833, J. F. Royle 132 (Geneva G 00452591).

Bondarenko (1962) included 25 species to the 6th volume of the Flora of Uzbekistan, but E. andryaloides has not been reported in it. This species has previously been known from NW India, Western Pamir, in South Tajikistan and Afganistan (Tamaschyan, 1959). Our recent studies on TASH collections 


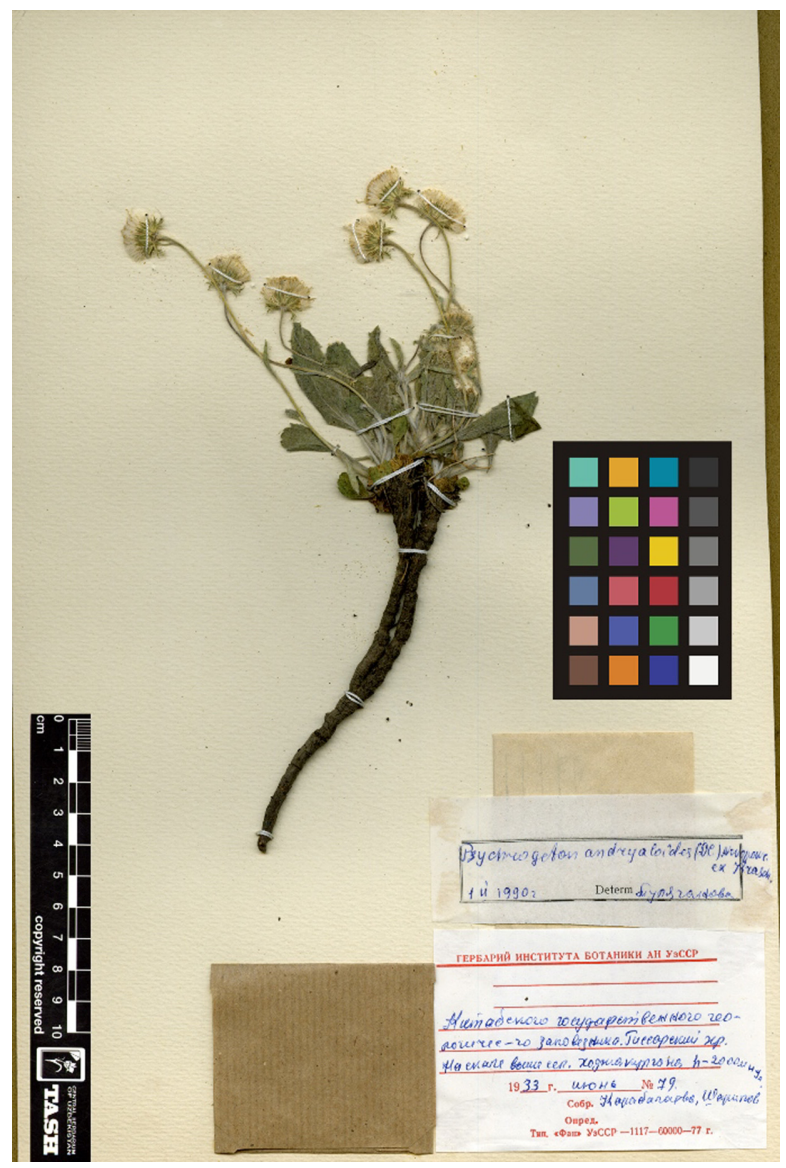

Fig. 11. Representative specimen of Erigeron andryaloides. have shown that one specimen of E. andryaloides was collected from territory of Uzbekistan and several specimens from Tajik part of the Eastern Pamir (Fig. 11).

Specimens examined: Uzbekistan. Kitab State Geological Reserve, Hissar range, on the rocky above the village of Khodja-Kurgan, 2,000 m, 6 Jun 1933, Karabacharova, Sharipov $79 I$ (TASH).

Tajikistan. Eastern Pamir. River basin Ak-su, the meadows under Ak-tash, 5 Aug 1935, Stanyukovich, Adilkhodzhaev 261 (TASH); Eastern Pamir. The river valley of the Tokuz-Bulak, near Koi-Tezek pass, 16 Sep 1935, Karpov, Yulin s.n. (TASH); Eastern Pamir. The Alichur River basin, river valley Bash-Gumbaz, East. Moraine slope, on stony deposits, 10 Jul 1936, Nazarenko 48 (TASH); Eastern Pamir. The Alichur River basin, lake Bulun-kul, 26 Jul 1934, Nikiforova, Sovetkina 200 (TASH); Eastern Pamir. Hospital Bashumbambas, 12 Jul 1935, Nazarenko, Margalina 69 (TASH); Pamir. River valley of Kalama, hole Sauk-Tash, rocky slope, 20 Jul 1936, Yakimova 74 (TASH).

Distribution: South Central Asia-from Tibet through Tajikistan to northern India through Afghanistan, Tajikistan. Also found in Uzbekistan on the rocky slopes of the western Hissar range.

Distribution map of ten newly recorded species is shown in Fig. 12.

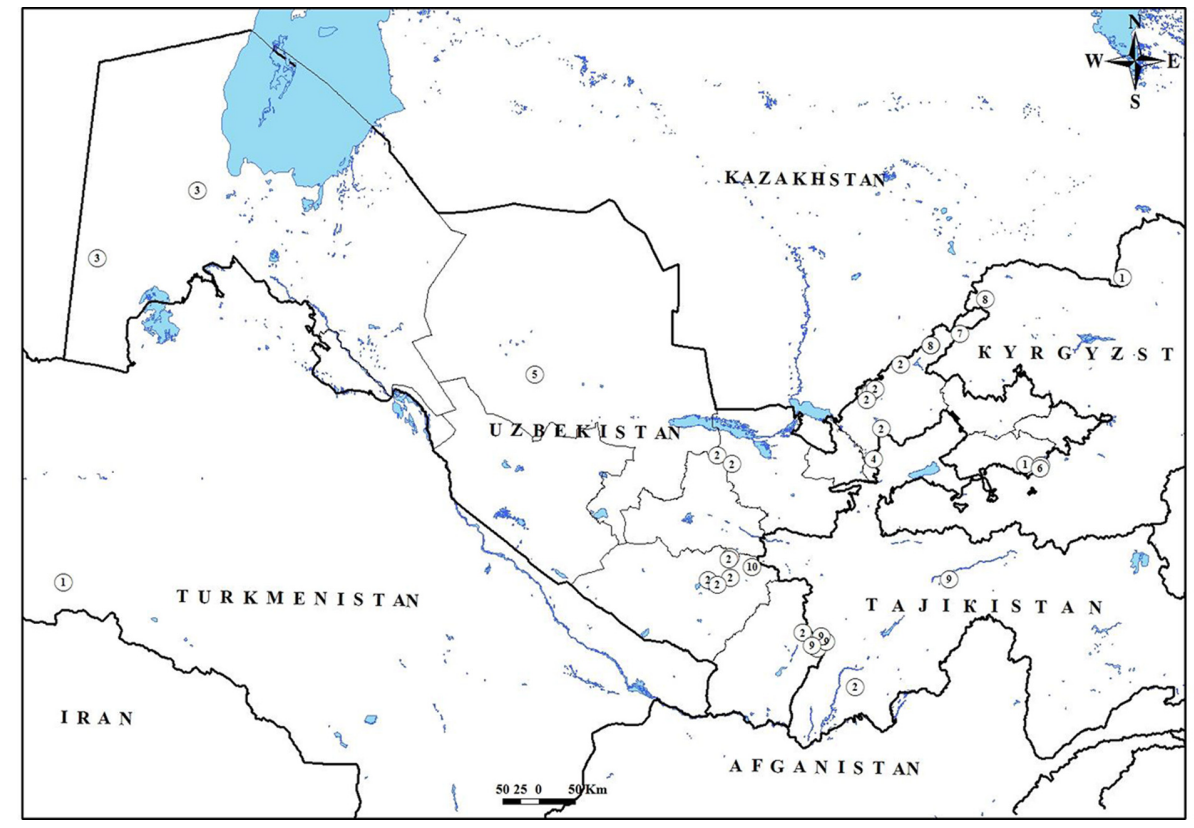

Fig. 12. Distribution map of the new species: 1. Anthemis ruthenica, 2. Carduus arabicus, 3. Centaurea scabiosa L. subsp. apiculata, 4. Chondrilla brevirostris, 5. Chondrilla macrocarpa, 6. Chondrilla phaeocephala, 7. Crinitaria tatarica, 8. Crepis mira, 9. Olgaea baldschuanica, 10. Erigeron andryaloides in Uzbekistan (according to herbarium and new collected specimens). 


\section{Acknowledgments}

This work was supported by the "The Flora of Uzbekistan Project [BA-ФA-Ф5-010])". Authors thank to A. Gaziev and T. Tillaev, that they were agreed to use the plant pictures, which took off from field expeditions. Also we would like to thanks to the Central herbarium (TASH) staffs for they carefully helped with species database and two anonymous reviewers that made very useful suggestions for improving the manuscript.

\section{Literature Cited}

Aydarova, R. A. 1965. Lactuca L. In Flora of the Kyrgyz SSR. Vol. 11. Vvedensky A. I. (ed.), Frunze. P. 450. (in Russian)

Bondarenko, O. N. 1962. Erigeron L. In Flora of Uzbekistan. Vol. 6. Vvedensky A. I. (ed.), Academia Scientarum USSR, Tashkent. Pp. 47-65 (in Russian)

Bushnev, A. N. and A. P. Pritvorov. 2017. Atlas of the World: As Detailed as Possible. AST, Moscow, 96 pp. (in Russian)

Central Intelligence Agency (CIA). 2017. The World Factbook. Retrieved Aug. 20, 2017. Available from www.cia.gov/library/ publications/the-world-factbook/geos/uz.html\#Geo.

Christenhusz, M. J. M. and J. W. Byng. 2016. The number of known plants species in the world and its annual increase. Phytotaxa 261: 201-217.

French, C. N., R. J. Murphy and M. Atkinson. 1999. Flora of Cornwall. Wheal Seton Press, Camborne, 400 pp.

Kamelin, R. V. and S. S. Kovalevskaya. 1993. Anthemis L. In Conspectus Florae Asiae Mediae. Vol. 10. Vvedensky, A. I. and R. V. Kamelin (eds.), Tashkent. P. 517. (in Russian)

Kovalevskaya, S. S. 1962. Chondrilla L. Flora of Uzbekistan. Vol. 6. Vvedensky A. I. (ed.), Academia Scientarum USSR, Tashkent. Pp. 450-454. (in Russian)

Karmyscheva, N. X. 1966. Lactuca L. In Flora of Kazakhstan. Vol. 9. Pavlov, N. V. (ed.), Academy of Sciences of Kazakh SSR, Alma-Ata. P. 522. (in Russian)

Khalkuziev, P. Kh. 1971. The flora and vegetation of Shahimardan river basin: Abstract of $\mathrm{PhD}$ dissertation. Tashkent. P. 180-185. (in Russian).

Lazkov, G. A. and B. A. Sultanova. 2014. Checklist of Vascular Plants of Kyrgyzstan. United Nations Development Programme, Bishkek, 126 pp. (in Russian)

Leonova T.G. 1964. Chondrilla L. In Flora of USSR. Vol. 29. Bobrov, E. G. and N. N. Tzvelev (ed.), Leningrad. Pp. 577-
581. (in Russian).

Makhmedov, A. M. 1993. Centaurea L. In Conspectus Florae Asiae Mediae. Vol. 10. Vvedensky A. I. and R. V. Kamelin (eds.), Tashkent. P. 411. (in Russian).

Orazova, A. 1966. Anthemis L. In Flora of Kazakhstan. Vol. 9. Pavlov, N. V. (ed.), Nauka, Alma-Ata. Pp. 5-9. (in Russian).

Rasulova, M. R. and B. A. Sharipova. 1991. Carduus L. In Flora of the Tajik SSR. Vol. 10. Rasulova M.R. (ed.), Nauka Press, Moskov \& Leningrad. P. 195. (in Russian).

Saliev, A. S. and Sh. B. Kurbanov. 2015. Demographic development of rural areas of the Republic of Uzbekistan. Socio-economic Geography: Bulletin of the Association of Russian Social Geographers 1: 151-152.

Sennikov, A. N. and G. Lazkov. 2014. New records in vascular plants alien to Kyrgyzstan. Biodivers Data Journal 2: e1018.

Sennikov, A. N., Tojibaev, K. Sh., Khassanov, F. O. and N. Yu. Beshko. 2016. The Flora of Uzbekistan Project. Phytotaxa 282: 107-118.

Sharipova, B. A. 1991. Olgaea Iljin In Flora of the Tajik SSR. Vol. 10. Rasulova M.R. (ed.), Nauka Press, Moskov \& Leningrad. P. 199. (in Russian).

Tamaschyan, S. G. 1959. Erigeron L. In Flora of USSR. Vol. 25. Shishkin, B. K. (ed.), Academy of Sciences of the USSR, Moskow \& Leningrad. Pp. 274?275. (in Russian)

Togayev, I. U. 1991. Chondrilla L. In: Conspectus Florae Asiae Mediae. Vol. 10. Vvedensky, A. I. and R. V. Kamelin (eds.), Tashkent. P. 119. (in Russian)

Tojibaev, K., Beshko, N., Turginov, O. and D. Mirzalieva. 2014. New records for Fabaceae in the flora of Uzbekistan. Fl. Medit. 24: 25-35.

Tzvelov, N. N. 1959. Crinitaria Cass. In Flora of USSR. Vol. 25. Shishkin, B. K. (ed.), Academy of Sciences of the USSR, Moskow \& Leningrad. Pp. 177-179. (in Russian)

Tzvelev, N. N. 1963. Centaurea L. In Flora of USSR. Vol. 28. Bobrov, E. G. and S. K. Cherepanov (eds.), Academy of Sciences of the USSR, Mockow \& Leningrad. Pp. 506-507. (in Russian)

Uzbekistan High Point on Peakbagger. 2017. Retrieved Aug. 20, 2017, available from http://www.peakbagger.com/peak.aspxpid $=10486$.

Yang, Y., Z. Wang, J. Li, C. Gang, Y. Zhang, I. Odeh and J. Qi. 2016. Comparative assessment of grassland degradation dynamics in response to climate variation and human activities in China, Mongolia, Pakistan, and Uzbekistan from 200 to 2013. Journal of Arid Environments135: 164-172. 